\title{
Design and Development of a Tractor Drawn Automatic Onion Transplanter
}

\author{
Lokesh Kumawat $^{*}$, H. Raheman ${ }^{1}$ and Vikas Singh ${ }^{2}$ \\ ${ }^{1}$ Agricultural and Food Engineering Department, IIT Kharagpur, 721302, India \\ ${ }^{2}$ Mahindra and Mahindra, Swaraj division $R \& D$ Centre, Mohali, Punjab, India
}

*Corresponding author

\section{Keyw ords \\ Onion transplanter; Hexagonal shaped paper pot chain; Conveying unit; Rotary cutters; Vertical blade; Field efficiency; Missing indexand Multiple index \\ Article Info \\ Accepted: \\ 18 January 2020 \\ Available Online: \\ 10 February 2020}

\section{A B S T R A C T}

A $15 \mathrm{hp} \mathrm{mini} \mathrm{tractor} \mathrm{operated} \mathrm{4-row} \mathrm{automatic} \mathrm{onion} \mathrm{transplanter} \mathrm{was} \mathrm{developed} \mathrm{to}$ transplant onion seedlings raised in hexagonal shaped (honeycomb) paper pot chain of length $800 \mathrm{~mm}$, width $180 \mathrm{~mm}$ and depth $40 \mathrm{~mm}$. A total of 128 seedlings were raised in this paper pot chain. The onion transplanter was developed to transplant 4-rows of onion seedlings at a time with a spacing of $10 \mathrm{~cm}$ between each row. It consisted of a furrow opener, a covering device, conveying belt and cutting units, a seedling delivery tube for each of the four rows and two ridgers for making two ridgeseach of $40 \mathrm{~cm}$ wide at the top. Belt-type conveying unit was employed for the movement of the paper pots. On the conveyor, paper pot chain was put and it conveyed the same to the furrow opener through the seedling delivery tubes after singulation using two types of cutting units i.e. three rotary cutters and a vertical blade. The rotary cutters were used to tear the paper pot chain lengthwise along the rows whereas one vertical blade was used to cut the paper pot chain perpendicular to the rows so that seedlings were singulated and one seedling was available for each seedling delivery tube at a time. Rotary cutters were powered by ground drive wheel whereas vertical blade was powered by a $12 \mathrm{~V} 600 \mathrm{~W}$ DC motor using the tractor battery. The developed automatic onion transplanter was tested in the field with alluvial soil (M. C. $20.3 \% \mathrm{db}$ ) at an average forward speed of $3.0 \mathrm{~km} / \mathrm{h}$. The average row to row spacing, plant to plant spacing and depth of placement were found to be $8.12 \mathrm{~cm}, 20.3 \mathrm{~cm}$, and $2.99 \mathrm{~cm}$, respectively. The average effective field capacity of the developed transplanter for transplanting onion seedlings was found to be $0.071 \mathrm{ha} / \mathrm{h}$ with a field efficiency of $71.25 \%$ andaverage missing index and multiple index was found to be $33 \%$ and $18.77 \%$, respectively.

\section{Introduction}

Onion can be grown from both seed and transplants. Large bulb (more than $5 \mathrm{~cm}$ in diameter) were obtained from the transplanted seedlings compared to the directly sown seeds (Gaafer et al., 1979). Torres et al., (1986) reported a yield of 20.3 to 35.8 ton $\mathrm{ha}^{-1}$ from transplanted onion compared to 10.3 ton $\mathrm{ha}^{-1}$ from the direct-sown onion in Brazil. However, growing onion directly from seed is not very popular because of non-uniformity in spacing leading to a reduction in crop yield due to restricted growth of onion bulbs 
(George, 2009). For using onion transplants, at first onion seedlings are raised on beds $3 \mathrm{~m}$ $\mathrm{x} 2 \mathrm{~m}$. The seed rate recommended for nursery rising is 8 to $10 \mathrm{~kg} / \mathrm{ha}$. The shallow furrows are opened to place the seeds and are then covered lightly. Water is then sprinkled on the beds. It takes about 6 to 8 weeks for the seedlings of onion to attain a height of 150 to $200 \mathrm{~mm}$ and develop a pea-size bulb when they are ready for transplanting in the field. Transplanting operation of bare root seedling of onion is most suitable when the plant height is $150 \mathrm{~mm}$ and neck diameter is $8 \mathrm{~mm}$ and it requires about 8 weeks for the seeds to reach this stage (Anon., 2017a). However, depending on soil, climate, and availability of rainfall, it can vary from 6-10 weeks.

The practice of topping seedlings at the time of transplanting if seedlings are over-grown is also prevalent. Onion seedlings of 6-8 weeks old are then transferred manually from nursery to the beds. The traditional method of transplanting consumes considerable time and demands higher labor, hence expensive. Therefore there is non-uniformity in plant distribution in traditional transplanting (Parish, 2005; Kumar and Raheman, 2008; Manes et al., 2010). Labor requirement for manual transplanting of vegetables varies from 240 to 320 man-h/ha (Kumar and Raheman, 2012).

There are a few reasons for the lack of advancement in the mechanization of automatic onion transplanter. Onion bulbs are very delicate and perishable for mechanical transplanting and single seedling should be sown at a place with proper spacing between plants. A special type of nursery preparation is the pre-requisite to develop automatic onion transplanter. Pot seedlings seem to be a better option due to the ability of pots to decompose, lower cost and easein preparation (Kumar and Raheman, 2008).
The advantage of potted plants is that the gravitational fall of seedlings can be applied to automate the transplanting operation with reduced complexity of the metering device. The use of bare-root seedlings in automatic planting devices is difficult because the planting device requires feeding, singulation, selection, alignment and transfer of seedlings, which are difficult to accomplish using bareroot seedlings (Suggs et al., 1987). The vegetable transplanters available are either semi-automatic or automatic type. In semiautomatic transplanters, the plants are fed by hand into the plant-placing device, whereas in automatic type preloaded plant cartridges or potted plants, stacked on the planter, are mechanically conveyed and placed in the ground. In automatic transplanters, the labor is partially reduced compared to semiautomatic machines (Nandede and Raheman, 2015). Transplanting of onion seedlings requires more labors and it is time-consuming which makes the farmers opt for the broadcasting of seeds, which results in low bulb yield and poor quality of bulbs. Considering the different problems identified in the mechanization of onion cultivation especially the labor requirement during the peak period of onion transplanting, it is required to develop an automatic onion transplanter. Hence, an attempt was made to design and develop a tractor-drawn automatic onion transplanter.

\section{Materials and Methods}

\section{Chain type paper pot seedlings for mechanical transplanting}

The first step in developing an automatic onion transplanter is to raise onion seedlings. A nursery of onion seedlings was prepared in honeycomb shaped chain type paper pots as shown in Fig. 1aSingle onion seeds were sown in an each cell of paper pots filled with potting mix (Farm yard manure, sand, and soil 
in a ratio of $1: 2: 2$ ). The length, width and depth of cells of the paper pot chain were 800 $\mathrm{mm}, 180 \mathrm{~mm}$, and $40 \mathrm{~mm} \mathrm{128}$, respectively. The total number of seedlings in a single chain were 128. At the time of transplanting onion seedlings were topped and height of onion seedlings were kept $6 \mathrm{~cm}$. The Shape of a single cell was hexagonal and length, width and depth of the single-cell were $45 \mathrm{~mm}, 25$ $\mathrm{mm}$ and $40 \mathrm{~mm}$, respectively as shown in Fig. 1 (b and $c)$.

\section{Components of the developed onion transplanter for handling paper pot seedlings}

The onion transplanter comprised, one conveying unit, cutting unit, furrow opener, furrow closer, seedling delivery tube, ridger and a ground wheel.

\section{Development of conveying unit}

A conveying unit comprising four pieces of rubber belt of length $1875 \mathrm{~mm}$, thickness 3 $\mathrm{mm}$ and width 40 was used to move the honeycomb shaped paper pot chain to the cutting unit when placed on the transplanter. This belt was capable to convey $20 \mathrm{~kg}$ of weight. The motion of the belt was made intermittent by using a Geneva mechanism to transmit power from the ground wheel to the conveyor roller.

The Geneva mechanism developed consisted of a Geneva wheel and a crank as shown in Fig. $2 \mathrm{a}$ and $2 \mathrm{~b}$. The rotating drive wheel i.e. crank had a pin that moved into a slot of the driven wheel i.e. Geneva wheel which was mounted on the shaft of the conveyor roller.

The design of the Geneva mechanism was dependent on radius of the crank, the diameter of roller and the number of slots present in the Geneva wheel. Number of slots on Geneva wheel was calculated using Eq. (1) (Anon., 2017b).
Taking roller diameter $(\mathrm{RD})=57.70 \mathrm{~mm}$, thickness of conveyor belt $=3 \mathrm{~mm}$, crank radius $=25$

$\mathrm{N}=\frac{\pi \times(\mathrm{RD}+2 \times \mathrm{t})}{25}=8$

\section{Development of cutting unit}

The cutting unit was required to cut the paper pot chain for singulation of seedlings. Three rotary cutters of diameter $120 \mathrm{~mm}$ were chosen to tear the paper along the row of paper pot chain so that a strip of the chain would move forward. A vertical blade was used to cut paper pot chain across the row so that a single cell could come outside the conveyor. The length, breadth, and thickness of the vertical blade were $160 \mathrm{~mm}, 50 \mathrm{~mm}$, and $2 \mathrm{~mm}$, respectively (Fig. 3) and it was moved up and down by a $12 \mathrm{~V} 600 \mathrm{~W}$ DCmotor.

\section{Development of furrow opener}

Since narrow strip was required to put the seedling in the proper furrow, hence shoe type furrow opener was chosen due to less draft requirement. Draft force for each furrow opener was calculated using Eq. (2).

$\mathrm{D}=\mathrm{k}_{0} \times \mathrm{w} \times \mathrm{d}(2)$

$\mathrm{D}(\mathrm{kgf})=$ draft force, $\mathrm{w}(\mathrm{cm})=$ width of opener, $\mathrm{d}(\mathrm{cm})=$ depth of opener,

$\mathrm{k} 0\left(\mathrm{~kg} / \mathrm{cm}^{2}\right)=$ Specific soil resistance $=0.25$ Taking, $\mathrm{w}=45 \mathrm{~mm}, \mathrm{~d}=40 \mathrm{~mm}$ and

$\mathrm{k}_{0}=1 \mathrm{~kg} / \mathrm{cm}^{2}$ considering factor of safety

Total draft force for four furrow openers was obtained as18.0 kgf.

Since shank of furrow opener is similar to cantilever beam, hence the maximum bending 
moment acting on the shank for a length of $400 \mathrm{~mm}$ cantilever beam was calculated using Eq. (3) and it was obtained $720 \mathrm{kgf}-\mathrm{cm}$.

$\mathrm{M}=$ Draft (kgf) x length of shank (cm) (3)

Using the maximum bending moment acting on shank, size of furrow opener was calculated. And considering the factor of safety of 2 and availability of material of standard size, $5 \mathrm{~mm}$ of thickness of furrow opener was selected.

\section{Development of furrow closer}

A pair of rectangular shape plate as covering device of $60 \mathrm{~mm}$ length was decided for each row to cover the onion seedlings with small amount of soil around it as roots of onion seedlings requires very less soil around it. The rectangular shape plate was fixed at an angle so that seedlings would not be damaged. Furrow covering device was mounted at the backside of the boot of furrow opener. And it was sliding behind the furrow opener to collect soil around onion seedlings.

\section{Development of ground drive wheel}

A $500 \mathrm{~mm}$ ground wheel made by mild steel flat $50 \times 5 \mathrm{~mm}$ was used. The wheel was provided with 12 number of spikes of diameter $16 \mathrm{~mm}$ and height $70 \mathrm{~mm}$ each (Fig. 4). These spikes were provided to reduce slippage of wheel during operation in the field as power was taken from the ground wheel to conveyor roller and rotary cutter.

\section{Development of seedling delivery tube}

Onion Seedlings after singulation were conveyed to the end of the belt, from where, it fell into the furrow opened by the furrow opener through a feeding tube of size $55 \times 55$ $\times 2 \mathrm{~mm}$. There were four independent feeding tubes for four rows of onion transplants and were fixed to the main frame at an angle lesser than $25^{\circ}$.

\section{Development of tractor drawn onion transplanter}

The CAD model for the automatic onion transplanter developed using SOLIDWORKS-2016 is shown in Fig. 5 (a and $b$ ). The developed onion transplanteris shown in Fig. 6 ( $a$ and b). It comprised of (i) ridger (ii) furrow opener (iii) covering device (iv) seedling delivery tube (v) conveying unit i.e. belt conveyor (vi) cutting units i.e. rotary cutter and vertical blade.

The components used to make the onion transplanter were assembled on a frame (made of hollow square section pipe) of 1000 $\mathrm{mm}$ length and $400 \mathrm{~mm}$ width. Hitching points were provided to attach this transplanter to the three-point linkage of the tractor.

\section{Power transmission system}

Three components of the developed transplanter required power to operate. Conveyor roller and rotary cutter were taking power from ground drive wheel and the vertical blade was powered by a $12 \mathrm{~V} 600 \mathrm{~W}$ DC motor connected to the tractor battery. The motor operated a slider crank mechanism to provide upward and downward movement of the vertical blade and the movement of vertical blade was kept around $7 \mathrm{~cm}$ so that onion seedlings were not damaged during cutting.

A Geneva mechanism was used to synchronize conveyor belt and vertical blade by maintaining a gear ratio of $8: 1$ between the ground drive wheel and crank of Geneva mechanism so that when conveyor belt was moving, the vertical blade was in stationary condition and vice-versa. With the help of 
Geneva wheel and crank continuous motion of ground wheel was changed to intermittent motion of conveyor belt to synchronize movement of vertical blade and movement of conveyor belt.

\section{Working of 4-row tractor drawn automatic transplanter}

The tractor drawn automatic onion transplanter covered 4-rows at a time in the soil bed of $400 \mathrm{~mm}$ width made by the ridger. The feeding tray of onion seedlings was put on the conveying belt which was moved at a speed of $0.30 \mathrm{~m} / \mathrm{s}$ taking power from a ground wheel drive to provide forward motion to the paper pot chain.

The onion transplanter could able to transplant four pots simultaneously by cutting the paper pot chain and conveying the same to the furrow through seedling delivery tube. The speed of rotation of the belt was made intermittent by using a Geneva mechanism. There was a cutting unit comprising of a rotating cutter and vertical blade for cutting along the row and across the row, respectively, to get single pots from the chain of paper pots.

\section{Measurements of performance parameters during field operation}

\section{Measurement of forward speed of tractor}

Time (s) was noted down by the stopwatch to cover a known distance (m) during field operation. The forward speed of tractor was calculated by the Eq. (4)

Speed of operation $\left.(\mathrm{km} / \mathrm{h})=\frac{\text { Distance }}{\text { time }} \times 3.64\right)$

\section{Field efficiency}

Actual area and theoretical area covered by transplanter per unit time was noted down and field efficiency Eq. (6) was measured by dividing the actual area per unit time to theoretical area per unit time.

FE $(\%)=\frac{\text { Actual area covered per unit time taken }}{\text { theoritical area covered per unit time taken }}$

\section{Measurement of fuel consumption}

The fuel tank was filled to full capacity before and after the test. Amount of refueling after the test was noted down. This was divided by the time taken to transplant the entire plot to determine the fuel consumption per unit time.

\section{Missing index}

Missing index Eq. (6) was the indicator of seedlings skip desired spacing.

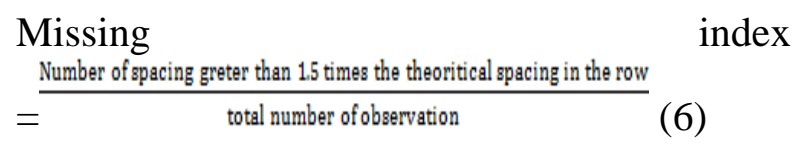

\section{Multiple index}

The multiple index Eq. (7) was the indicator of more than one seedlings dropped within a desired spacing.

Multiple
Number of of ppecing less than or equal to half of the theoritical spacing in the row
total number of observation

\section{Results and Discussion}

The detailed specification of the developed tractor drawn onion transplanter is given in Table 1.

The field tests of the developed tractor operated automatic onion transplanter were conducted at Morinda (Punjab). The details of the field tests are given in Table 2. Plot of size $1000 \mathrm{~m}^{2}$ was selected with having alluvial soil at an average moisture content of $20.3 \%$ (db.) and average bulk density of $1.49 \mathrm{~g} / \mathrm{cc}$. 
Table.1 Detailed specifications of the developed small scale automatic onion transplanter

\begin{tabular}{|c|c|c|}
\hline Sl. No. & Components & Specifications \\
\hline 1. & Power source & Tractor mounted (15 hp) \\
\hline 2. & \multicolumn{2}{|c|}{$\underline{\text { Overall dimensions }}$} \\
\hline i. & Length, mm & 1675 \\
\hline ii. & Width, mm & 1000 \\
\hline iii. & Height, mm & 670 \\
\hline 3. & Furrow opener & Shoe type \\
\hline 4. & Covering device & Sliding plate type \\
\hline 5. & \multicolumn{2}{|c|}{ Ground wheel drive } \\
\hline i. & Number & 1 \\
\hline ii. & Type & Spiked tooth type \\
\hline iii. & Overall diameter, $\mathrm{mm}$ & 660 \\
\hline iv. & Effective diameter, mm & 520 \\
\hline 6. & Power transmission system & Chain and sprocket \\
\hline 7. & Number of row & 4 \\
\hline 8. & Row to row spacing, mm & 100 \\
\hline 9. & Weight of the machine, $\mathrm{kg}$ & 114 \\
\hline
\end{tabular}

Table.2 The average values of field and operational parameters

\begin{tabular}{|l|c|}
\hline Performance Parameters & Average values \\
\hline Width of operation, mm & 400 \\
\hline Soil bulk density, g/cc & 1.57 \\
\hline Soil moisture content, \% db & 21.00 \\
\hline Row to row spacing, mm & 81.20 \\
\hline Plant to plant spacing, mm & 203.00 \\
\hline Height of seedlings, mm & 64.6 \\
\hline Speed of operation, km/h & 1.08 \\
\hline Wheel slippage, \% & 12.5 \\
\hline Planting depth of pot, mm & 29.9 \\
\hline Fuel consumption, $\mathbf{~ / h}$ & 2.18 \\
\hline Effective field capacity, ha/h & 0.071 \\
\hline Field efficiency, \% & 71.25 \\
\hline Missing index, \% & 33 \\
\hline Multiple index, \% & 18.77 \\
\hline
\end{tabular}


Fig.1a Onion seedlings raised in honeycomb shaped chain type paper pots

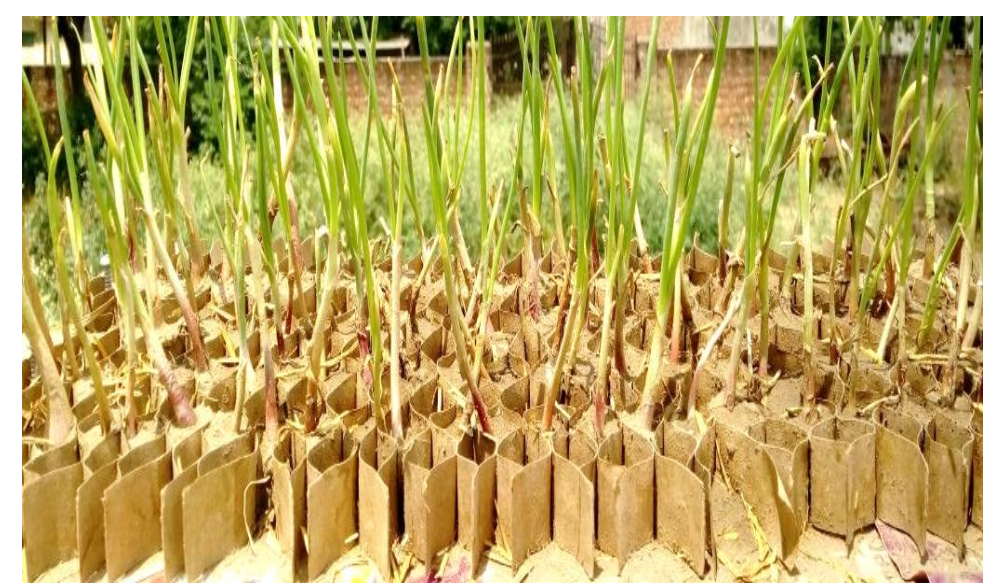

Fig.1b Schematic view of honey comb shape paper pot chain

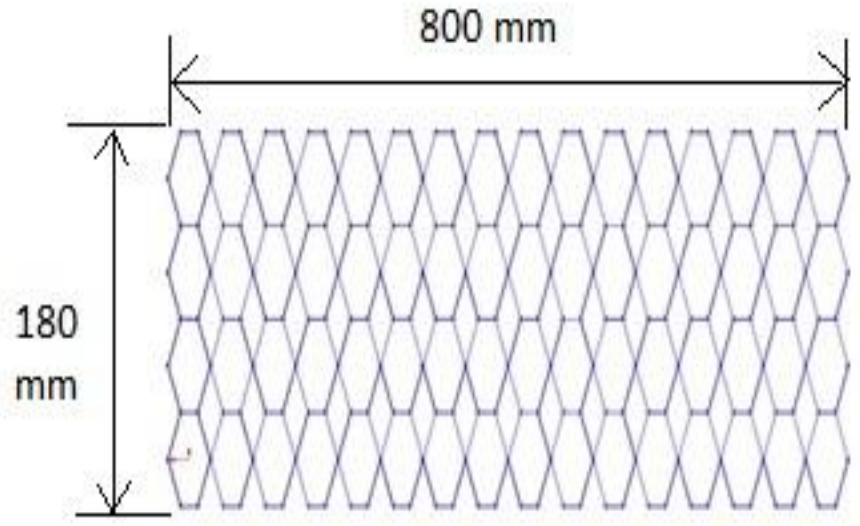

Fig.1c Schematic view of single hexagonal shape cell

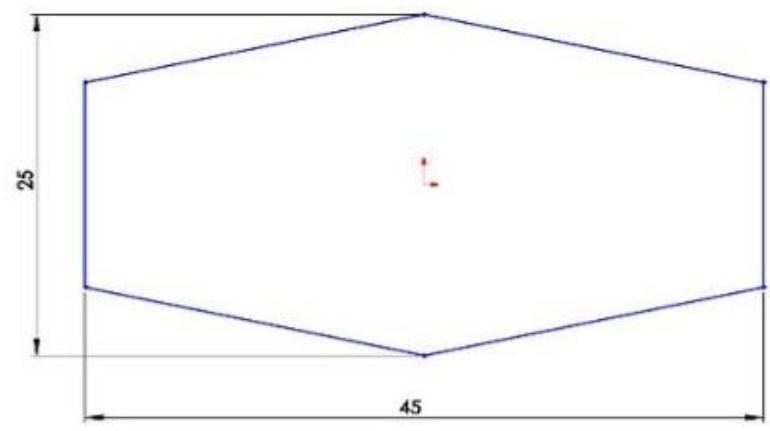


Fig.2a Schematic views of Geneva wheel
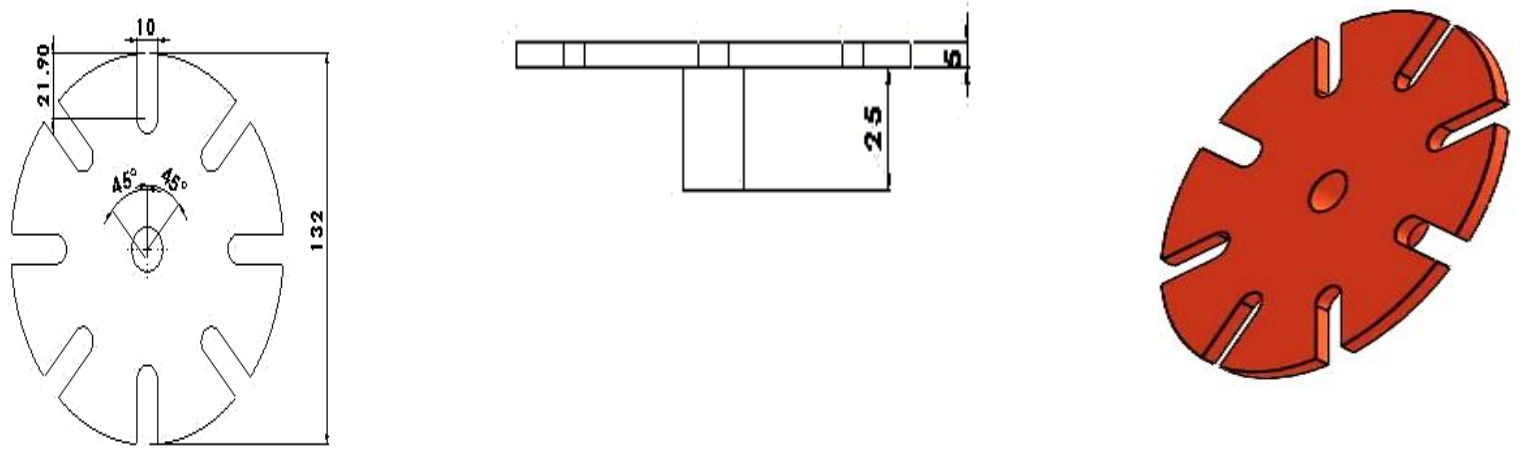

Fig.2b Schematic views of crank
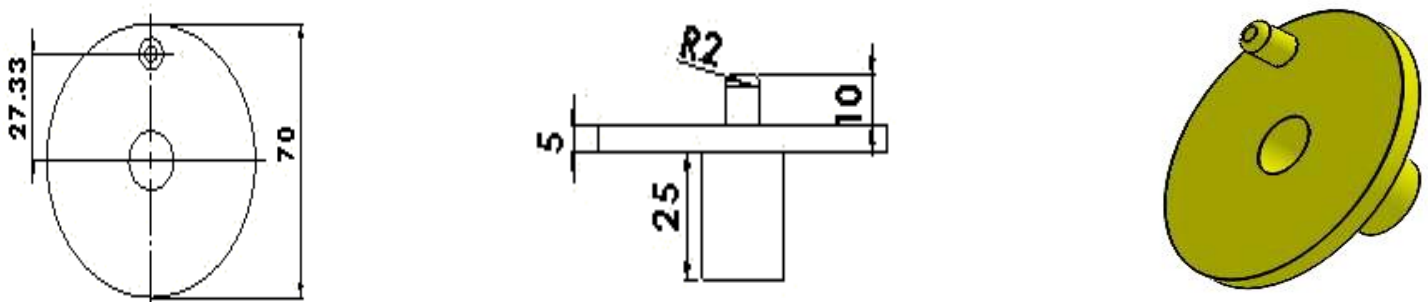

Fig.3 Closed view of cutting unit and Geneva mechanism

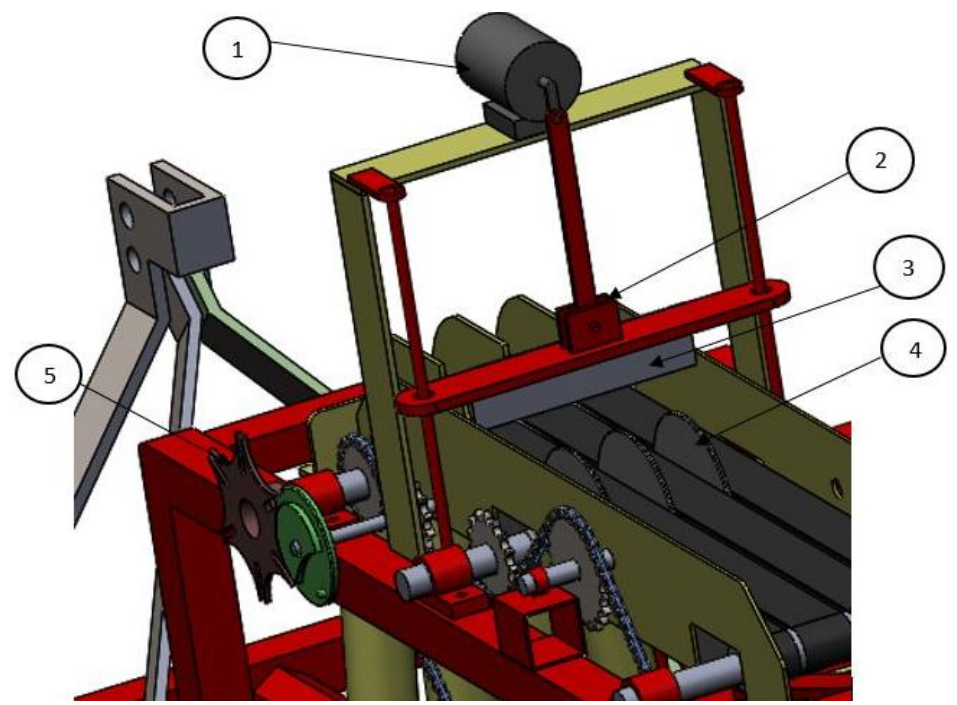

1. DC Motor 2. Slider crank mechanism 3. Vertical blade 4. Rotary cutter 5. Geneva mechanism 
Fig.4 Schematic views of closed spikes type ground wheel
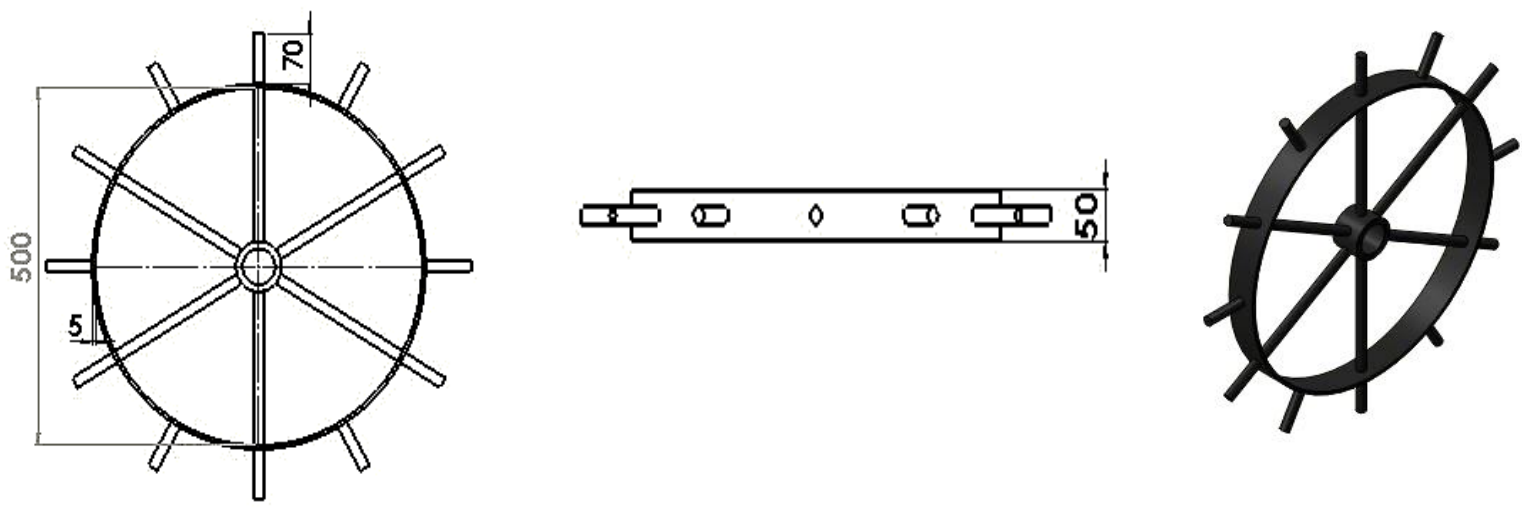

Fig.5a Pictorial view of onion transplanterattached to a tractor

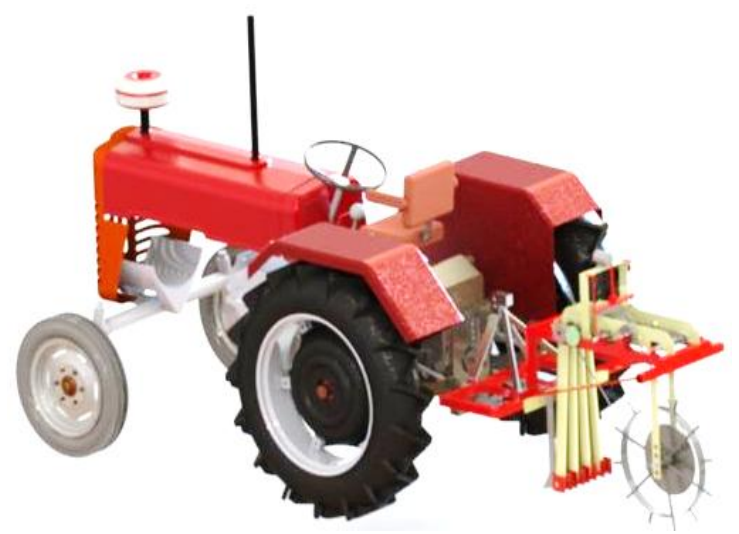

Fig.5b Schematic views of the onion transplanter

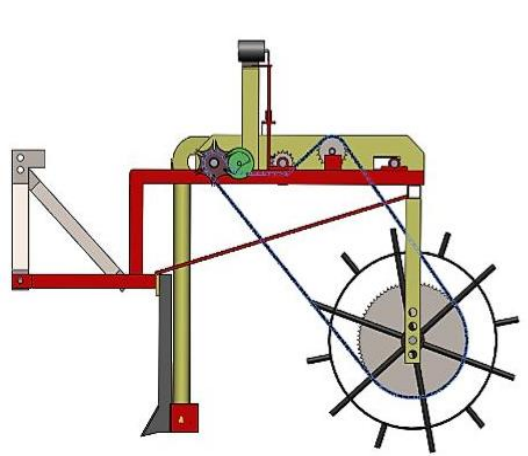

a) Side view

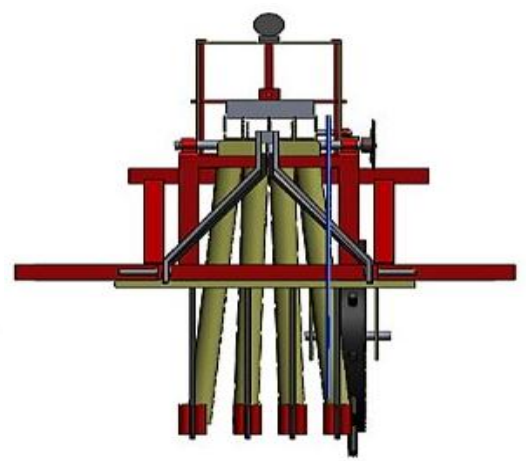

b) Front view 


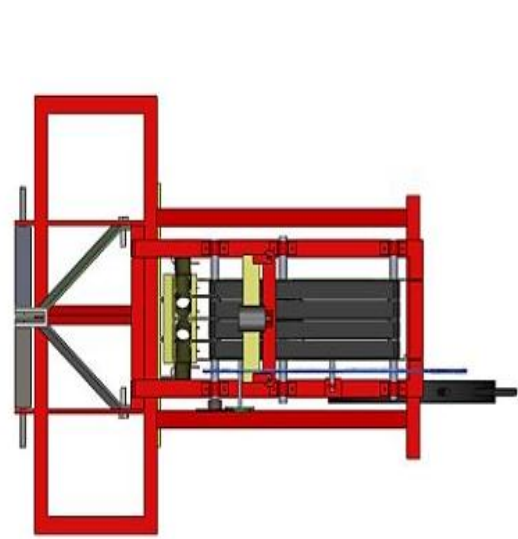

c) Top view

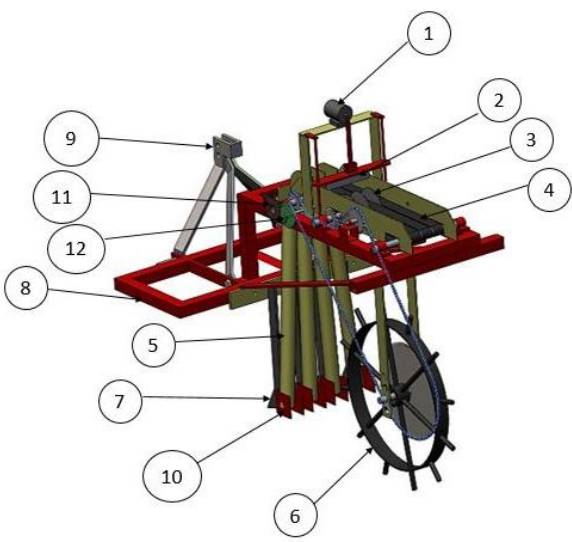

d) Isometric view

1. DC motor 2. Vertical blade 3. Rotary cutter 4. Conveyor belt 5. Seedling delivery tube

6. Ground wheel drive 7. Furrow opener 8. Hitching Frame 9. Three - point hitch 10. Furrow covering device 11. Geneva wheel 12. Crank

Fig.6a Tractor drawn automatic onion transplanter with feeding tray

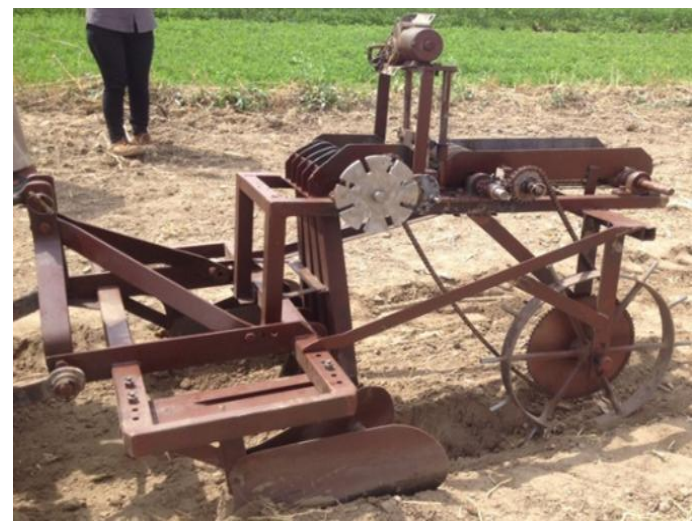

Fig.6b Side view of the developed onion transplanter

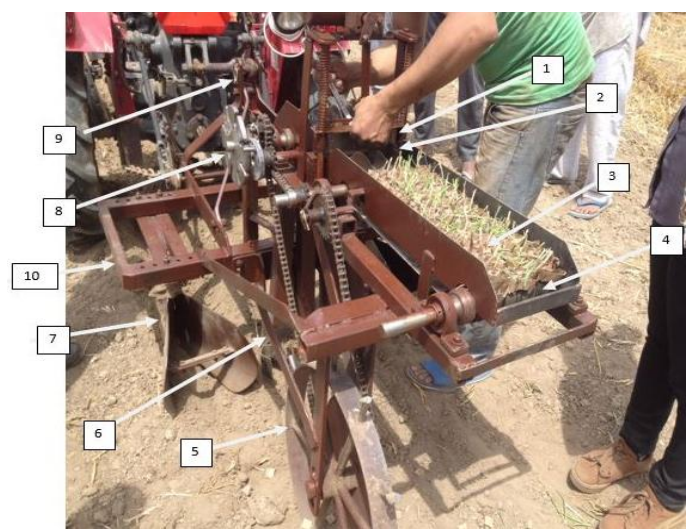

1. Vertical blade 2. Rotary cutter 3. Honeycomb paper pot chain 4. Conveyor belt 5. Ground wheel 6. Furrow opener 7. Ridger 8. Geneva wheel and Crank wheel 9. There point hitch 10. Hitching Frame 
Fig.8 Flow chart of power transmission system

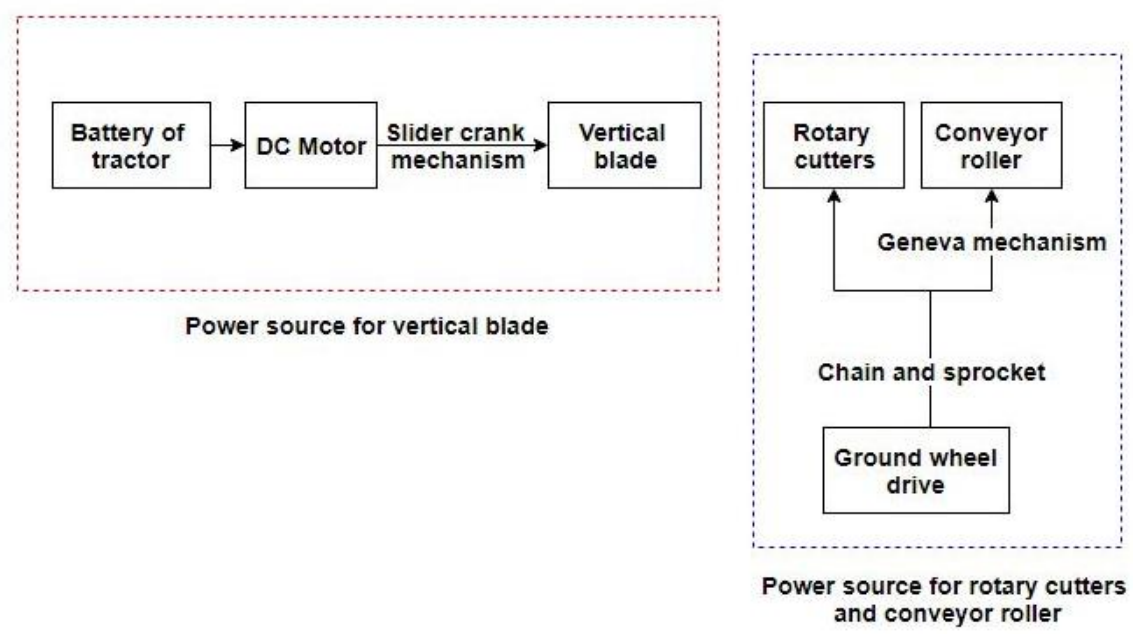

Fig.9 Speed of operation vs. field efficiency

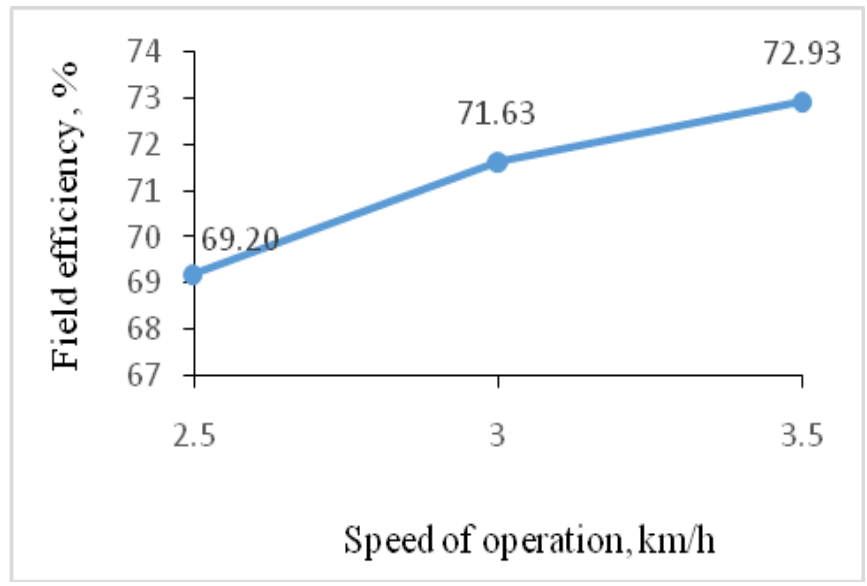

Fig.10 Speed of operation vs. fuel consumption

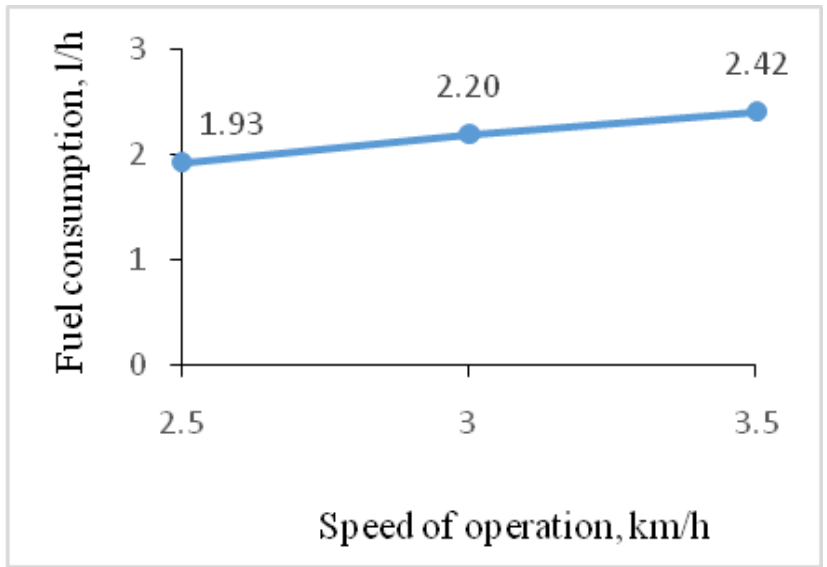


Fig.11 Speed of operation vs. missing index

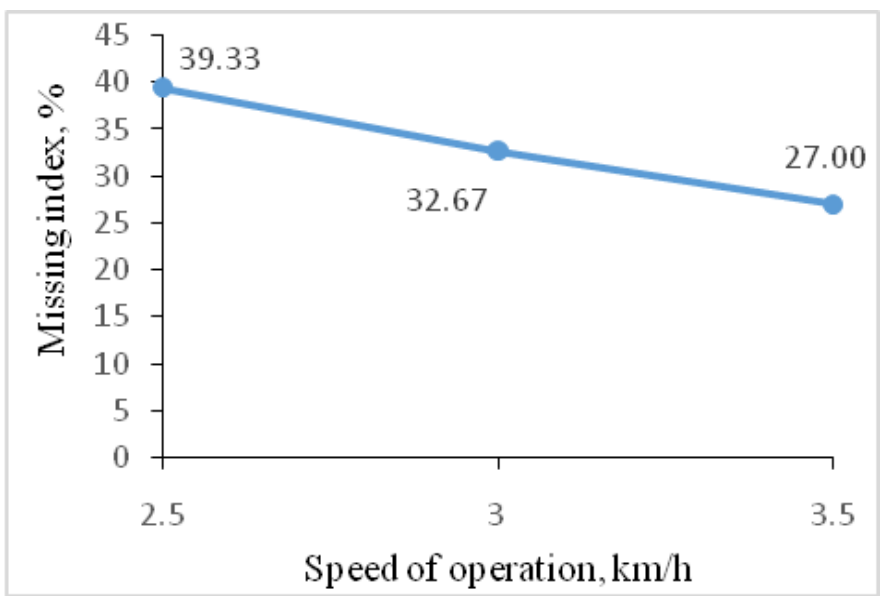

Fig.12. Speed of operation vs. multiple index

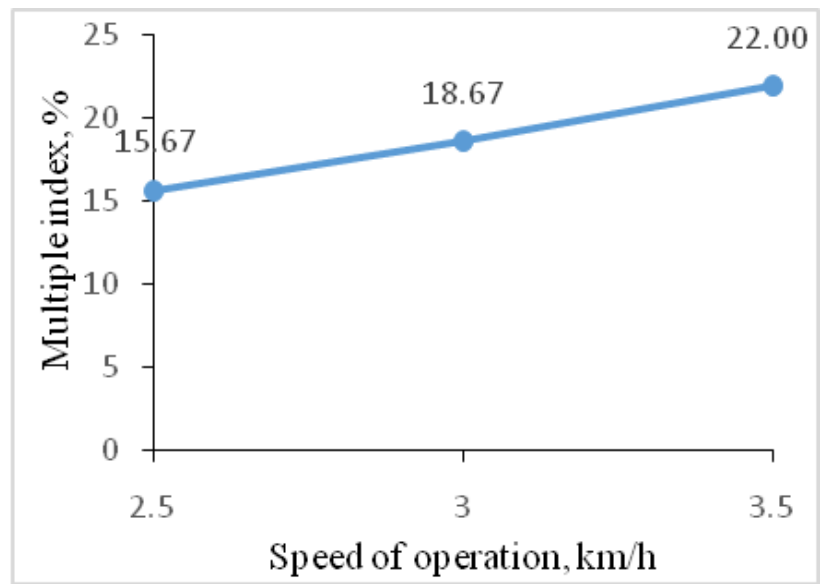

The onion seedlings were successfully raised in honeycomb chain type paper pot. Seedlings were ready for transplanting after 7 weeks (49 days) when the bulb diameter, height, and weight were $7.5 \mathrm{~mm}, 110 \mathrm{~mm}$ and $1.52 \mathrm{~g}$, respectively. The height of seedlings were restricted to $60 \mathrm{~mm}$ by trimming the top of the seedlings having more height at the time of transplanting. The tractor was operated at an average forward speed of $3.0 \mathrm{~km} / \mathrm{h}$. A total of 128 seedlings in each chain of paper pot were carried at a time. The transplanting operation was carried out along the length of the selected plot. The total time required for transplanting operation for the plot was noted down. The different performance parameters viz. effective field capacity, fuel consumption of tractor, percentage wheel slip and field efficiency were determined. After the completion of transplanting operation in each plot, the number of missed plantings were counted. The performance of the transplanter is summarized in Table 2.

It was observed that field efficiency increased with increase inspeed of operation as shown in fig. 9. The maximum field efficiency, $72.93 \%$ was observed at a speed of $3.5 \mathrm{~km} / \mathrm{h}$. Fuel consumption also increased with increase in forward speed of the machine (Fig. 10). Missing index decreased with increase in speed and was found to be lowest 
at the speed of $2.5 \mathrm{~km} / \mathrm{h}$ (Fig. 11); similarly multiple index was found to be higher at higher speed of machine and highest at a speed of $3.5 \mathrm{~km} / \mathrm{h}$ (Fig. 12).

In conclusion on the basis of field tests of the automatic onion transplanter, the following specific conclusions were drawn:

Seedlings were successfully raised in paper pot chain with potting mix (Farm yard manure, sand, and soil in a ratio of $1: 2: 2)$.

The developed transplanter could handle the seedlings raised in paper pot chain with an average effective field capacity of $0.071 \mathrm{ha} / \mathrm{h}$ and field efficiency of $71.25 \%$. This lower field efficiency was due to improper synchronization between the vertical cutting blade and conveying belt.

The average plant to plant spacing obtained in the experimental plots was $203 \mathrm{~mm}$ with depth of planting as $29.94 \mathrm{~mm}$. Increase in forward speed increased the plant to plant spacing, decreased planting depth and increased missing index and damaged seedling percentage. The average missing index and multiple index were observed as $33 \%$ and $18.77 \%$, respectively.

The fuel consumption for the operation of onion transplanter was found to be $2.18 \mathrm{l} / \mathrm{h}$. with a man- power requirement of $132 \mathrm{man}-\mathrm{h} / \mathrm{ha}$ as compared to $400-450 \mathrm{ha} / \mathrm{h}$ with the traditional method.

\section{Acknowledgements}

The present study was conducted under the framework of the Mahindra and Mahindra, Swaraj division R \& D Centre Mohali, Punjab. The authors sincerely acknowledge the financial support provided by Mahindra and Mahindra, Swaraj to carry out this research work.

\section{References}

Anon. 2017a. (http://agritech.tnau.ac.in /horticulture/horti_vegetables_small\% 20onion.html) accessed online 6-92017.

Anon. 2017b. Software link(http://benbrandt22.github.io/genevaG en) accessed online 6-9 2017.

Gaafer A K; Hafez A A; Abd-El-Hafez. 1979. Yield components of onion as affected by methods of planting under different fertilizer treatments. Egyptian J. of agronomy, 4,187-194.

George R. A. 2009. Vegetable seed production. Chapter 14 Alliaceae. CAB International. Wallingford, UK. pp 251-263.

Kumar G V P; Raheman H. 2008 Vegetable transplanters for use in developing countries: A review. International Journal of Vegetable Science, 14(3), 232-255.

Kumar G V P; Raheman H. 2010. Volume of vermicompost based potting mix for vegetable transplants Determined using fuzzy biomass growth index. International Journal of Vegetable Science, 16(4), 335-350.

Kumar G V P; Raheman H. 2012. Automatic feeding mechanism of a vegetable transplanter. Int J Agric\&BiolEng, $5(2)$.

Manes G S; Dixit A K; Sharda A; Singh S; Singh K. 2010. Development and evaluation of tractor operated vegetable transplanter. Agricultural Mechanization in Asia Africa and Latin America, 41(3), 89-92.

Nandede B M; Raheman H. 2015. MultiStage Metering Mechanism for Transplanting of Vegetable Seedlings in Paper Pots, 96(4), 295-300. 
Parish R L 2005. Current developments in seeders and planters for vegetable crops. Horticulture Technology, 15(2), $1-6$.

Suggs C W; Peel H B; Thomas T N; Eddington D L; Gore J W; Seaboch T R. 1987. Self-feeding transplanter for tobacco and vegetable crops. Appl. Eng. Agric., 3(2), 148-152.

Torres,I T J C; Amado T J C; Guimaraess D R. 1986. Minimum cultivation with onion growing in Santa Catarina. PrequisaemAndamento, Brazil 69, 4.

\section{How to cite this article:}

Lokesh Kumawat, H. Raheman ${ }^{1}$ and Vikas Singh. 2020. Design and Development of a Tractor Drawn Automatic Onion Transplanter, India. Int.J.Curr.Microbiol.App.Sci. 9(02): 2616-2629. doi: https://doi.org/10.20546/ijcmas.2020.902.299 